\title{
Functional Cytology of the Hepatopancreas of Palaemonetes argentinus (Crustacea, Decapoda, Caridea) Under Osmotic Stress
}

\author{
Ana Cristina Díaz ${ }^{2,3^{*}}$, Liliana Graciela Sousa ${ }^{3}$ and Ana María Petriella ${ }^{1,3}$ \\ ${ }^{1}$ Consejo Nacional de Investigaciones Científicas y Técnicas; Buenos Aires - Argentina. ${ }^{2}$ Comisión de \\ Investigaciones Científicas; Buenos Aires - Argentina. ${ }^{3}$ Departamento de Ciencias Marinas; Facultad de Ciencias \\ Exactas y Naturales; Universidad Nacional de Mar del Plata; Funes 3350; B7602AYL; Mar del Plata - Argentina
}

\begin{abstract}
The present work describes the effect of different salinities on the functional morphology of the P. argentinus hepatopancreas and analyses the tissue recovery after re-acclimation to freshwater. Adult prawns of both sexes at sexual rest were collected from a tributary of the Mar Chiquita coastal lagoon. The prawns were acclimated in aquaria to four salinity conditions: 0 (control), 8, 16 and 24\%o. To evaluate the possible tissular recovery, after 60 days individuals from all the treatments were gradually acclimated to freshwater and maintained for other 30 days. Hepatopancreas samples were processed at the beginning of the trial and every 30 days using standard histological techniques for OM and TEM. The individuals from all the treatments, except the controls, showed a continuous weight decrease, and survival was lower when higher the salinity. At 30 days from the beginning of the experiment, hepatopancreas from 16 and 24\%o salinities showed an enlarged tubular lumen and an infolded basal lamina. Ultratructurally, nuclear retraction, cytoplasmolysis, and RER membranes separated with electron-dense content were observed in all the treatments except 0\%. After 60 days, profound alterations were observed with the three treatments. After the re-acclimation period, there was no reestablishment of the functional cytology. The tolerance to short-term salinity changes explains the capability of this prawn to inhabit in estuarine environments.
\end{abstract}

Key words: Salinity, Histology, Hepatopancreas, $P$. argentinus

\section{INTRODUCTION}

The shrimps from the Family Palaemonidae inhabit seawater, brackish water and freshwater environments. Palaemonetes argentinus Nobili, 1901 is one of the most widely distributed decapods in the littoral fluvial region of Argentina, Paraguay, Uruguay, and southern Brazil (Boschi, 1981; Morrone and Lopreto, 1995). This prawn plays an important role in the trophic network of the environments it inhabits (Spivak, 1997;
Collins, 1999). It is considered a typical freshwater species; however, it has also been found in brackish coastal lagoons along the coast of the south western Atlantic Ocean (Anger et al., 1994). In these lagoons, salinity can be low (1 to 5\%o) for extended periods of several days, or it can vary between 1 and 30\%o within a few hours (Charmantier and Anger, 1999).

In crustacean, the hepatopancreas is the primary organ responsible of absorption and storage of ingested materials (Loizzi, 1971; Storch and

*Author for correspondence: acdiaz@mdp.edu.ar 
Welsch, 1977; Vogt et al., 1989; Johnston et al., 1998). This organ is also involved in the synthesis of digestive enzymes and the detoxification of xenobiotics (Gibson and Barker, 1979; Icely and Nott, 1992; Vogt, 1994). It consists of one or more lobules formed by tubules with blind ends at the distal zone and open ends at the proximal zone. Tubules converge into a primary duct, which connects the organ with the pyloric stomach (Icely and Nott, 1992, Sousa and Petriella, 2000).

Hepatopancreas epithelium is composed of four main cell types: E (embryonic) cells, confined to the blind distal ends, and $\mathrm{F}$ (fibrilar), $\mathrm{R}$ (resorptive) and B (blister-like) cells, distributed throughout the whole tubule with some variations according to the species (Icely and Nott, 1992; Petriella and Fonalleras, 1997; Sousa and Petriella, 2000; Sousa et al., 2005). The organ undergoes histological and histochemical modifications in response to different physiological demands (moult, reproduction) (Al-Mohanna and Nott, 1989; Sousa and Petriella, 2001) and environmental changes such as salinity (Masson, 2001; Cuartas et al., 2003) and pollution (Icely and Nott, 1992; Johnston et al., 1998).

The present work was performed to study the effect of different salinities on the functional morphology of $P$. argentinus hepatopancreas and to analyse the possible tissue recovery after reacclimation to freshwater.

\section{MATERIALS AND METHODS}

Adults prawns of both sexes at sexual rest (Boschi, 1981), weighing $0.170 \pm 0.008 \mathrm{~g}$ were collected from Sotelo stream, tributary of the Mar Chiquita coastal lagoon (Argentina, $38^{\circ} \mathrm{S} 55^{\circ} \mathrm{W}$ ), with a hand net. A four month experiment was carried out using 300 individuals. The prawns were reared in 301 aquaria with a sand and shell filter and gently aerated water at $22 \pm 1.8^{\circ} \mathrm{C}$ and $12: 12$ light/dark photoperiod. Freshwater for human consumption $(\mathrm{pH}=7.6)$ was used in the experiment. Mean total water hardness (as $\mathrm{CaCO}_{3}$ ) was $110 \mathrm{mg} \mathrm{l}^{-1}$, nitrite and nitrate were $0.01 \mathrm{mg} \mathrm{l}^{-1}$, and un-ionized ammonia was $0.01 \mathrm{mg} \mathrm{l}^{-1}$ (OSSE, 2005). They were gradually acclimated to four salinity conditions: 0 (control), 8, 16 and 24\%o. Salinity was adjusted by diluting the filtered seawater and monitored with an optical refractometer. Each treatment was carried out in triplicate with 25 prawns per aquarium at the beginning of the experiment.

To evaluate the possible tissular recovery, after 60 days the individuals from all the treatments were gradually acclimated to freshwater and were maintained for 30 days.

The individuals were fed daily with a pelletized diet $(45 \%$ proteins, $8 \%$ lipids, $7 \%$ moisture and $7 \%$ ash) prepared in the laboratory, whose efficiency was previously tested (Díaz et al., 2002). Prior to feeding, exuviae were collected; presence of any dead prawn was recorded and excess food was removed to preserve the water quality.

The animals were placed on ice and the cephalothorax integument was removed dissecting the organ. Hepatopancreas of wild animals were sampled at the beginning of the experiment and hepatopancreas of two individuals per aquarium were dissected every 30 days.

\section{Light microscopy}

For histological description, the hepatopancreas were fixed for $24 \mathrm{~h}$ in Davidson fluid (ethanol, formol, acetic acid and water) (Bell and Lightner, 1988), dehydrated in increasing concentration of ethanol, butyl alcohol (two changes of $24 \mathrm{~h}$ ), butyl-paraffin 50:50 (for $24 \mathrm{~h}$ ) and finally embedded in paraffin. Sections $(3 \mu \mathrm{m})$ were stained with Haematoxylin-Eosin.

\section{Transmission electron microscopy (TEM)}

The hepatopancreas were placed in $2.5 \%$ glutaraldehyde in $0.1 \mathrm{M}$ cacodylate buffer $(\mathrm{pH}=$ 7.2-7.4) at $4{ }^{\circ} \mathrm{C}$. They were postfixed in $1 \% \mathrm{OsO}_{4}$ for $1 \mathrm{~h}$. Later, the material was dehydrated through an ethanol series and embedded in Spurr resin. Semithin sections $(1 \mu \mathrm{m})$ were stained with toluidine blue. Ultrathin sections were mounted on copper grids (400mesh) and stained with lead citrate and uranyl acetate. TEM images were obtained with a JEOL JSM-100CX II transmission electron microscope.

\section{RESULTS}

During the experiment, the control individuals showed a good growth and survival (100\%), while individuals from the other three treatments showed a continuous weight decrease. The survival was lower when higher the salinity (Fig. 1, 2). 


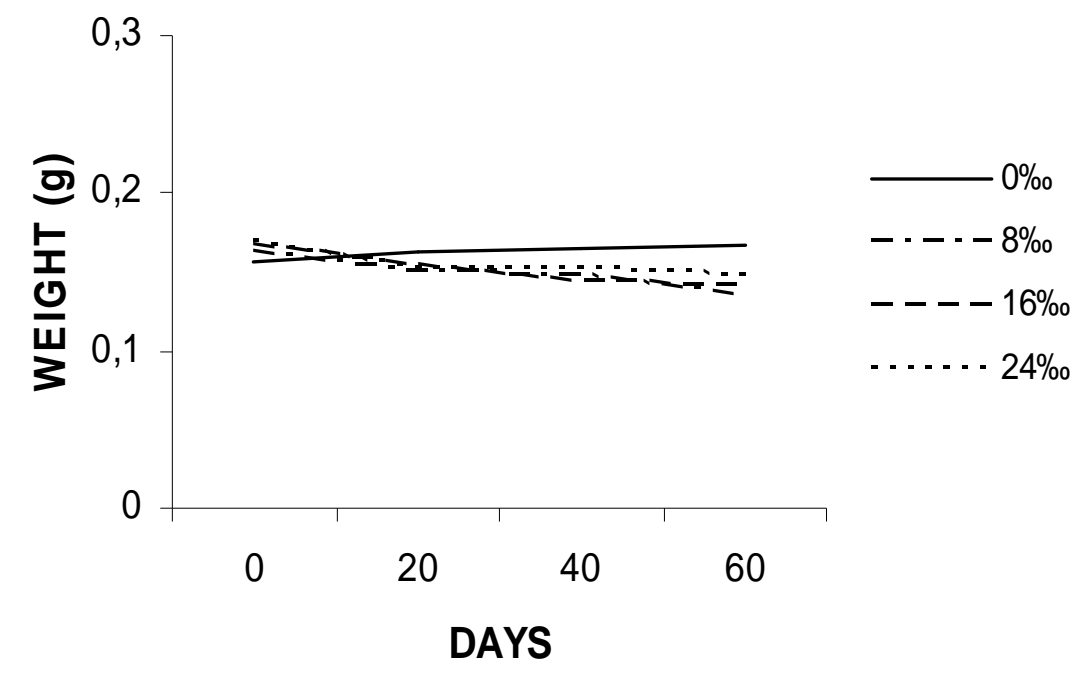

Figure 1 - Weight variation (g) of Palaemonetes argentinus for the four salinities.

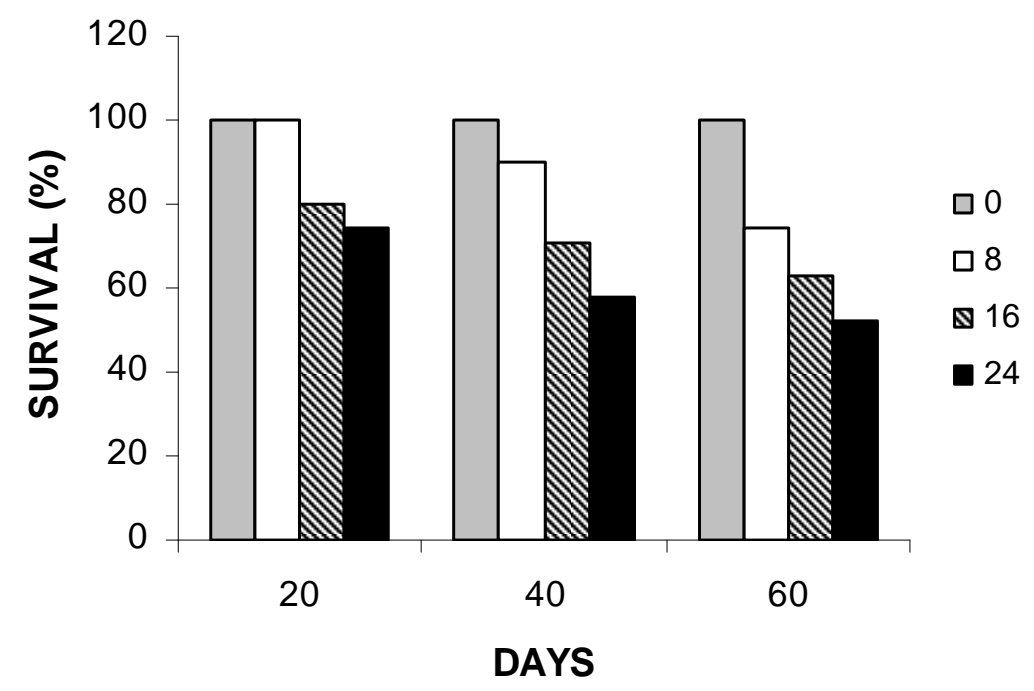

Figure 2 - Percentage of survival of $P$. argentinus reared at different salinities.

After 30 days, the individuals from all the treatments, except the controls (Fig. 3A-D), showed tissular alterations compared with the initial histological conditions. The tubular lumen was enlarged and the basal lamina of several tubules was infolded in the hepatopancreas of individuals maintained at 16 and 24\%o. Several ultrastructural alterations were detected. At $8 \%$, the main alterations observed were nuclear retraction, cytoplasmolysis in some cells, and RER membranes separated with electron-dense content (Fig. 4A-B). At 16\%o, the haemocytic infiltration was evident among the tubules, complete cytolysis in many cells, desquamated epithelium with haemolymph infiltration between cells and the basal lamina were other abnormal features 
observed (Fig. 4C-D). F-cells presented the RER membranes separated with electron-dense content and dilated Golgi cisternae. In some cells, mitochondria were partially fused.

At $24 \%$, significant amounts of haemocytes were observed among the tubules (Fig. 4E), mainly hyaline ones and some granulocytes. Cells showed cytoplasmolysis, retracted or pyknotic nuclei and spherical mitochondria with a few cisternae (Fig 4F).
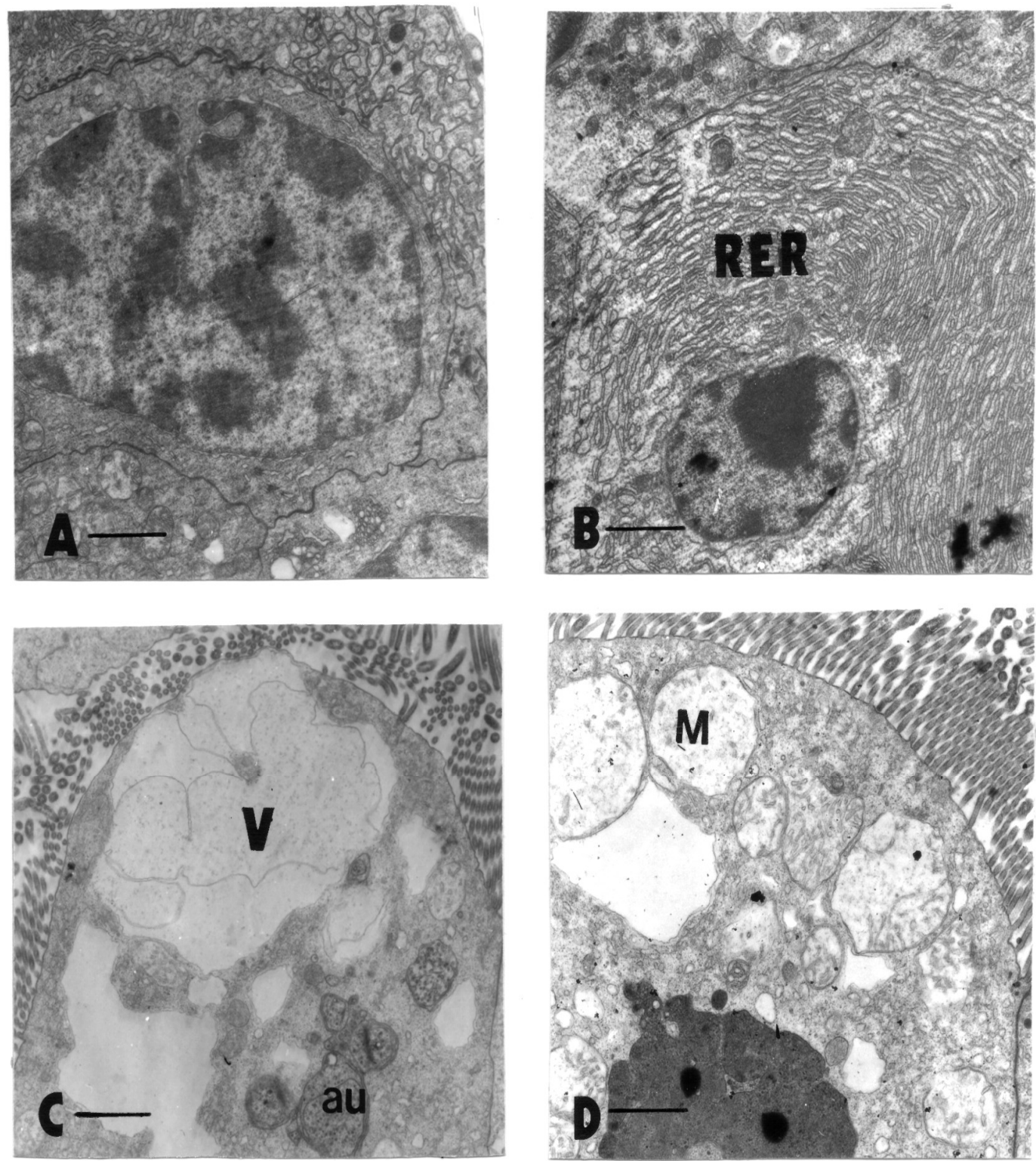

Figure 3 - Ultrastructural features of hepatopancreas cells of $P$. argentinus at the beginning of the experiment. -A. Embryonic cell (E-cell) with a high nucleus/cytoplasm rate and scarce organelles. Scale bar: $0.96 \mu \mathrm{m}-\mathrm{B}$. F-cell showing an extensive rough endoplasmic reticulum (RER). -C. B-cell with the incipient apical vacuole (V) and some autophagosomes (au). -D. R-cell; note the apical mitochondria (M), the conspicuous brush border and a residual body (rb). Scale bars: $1.8 \mu \mathrm{m}$. 

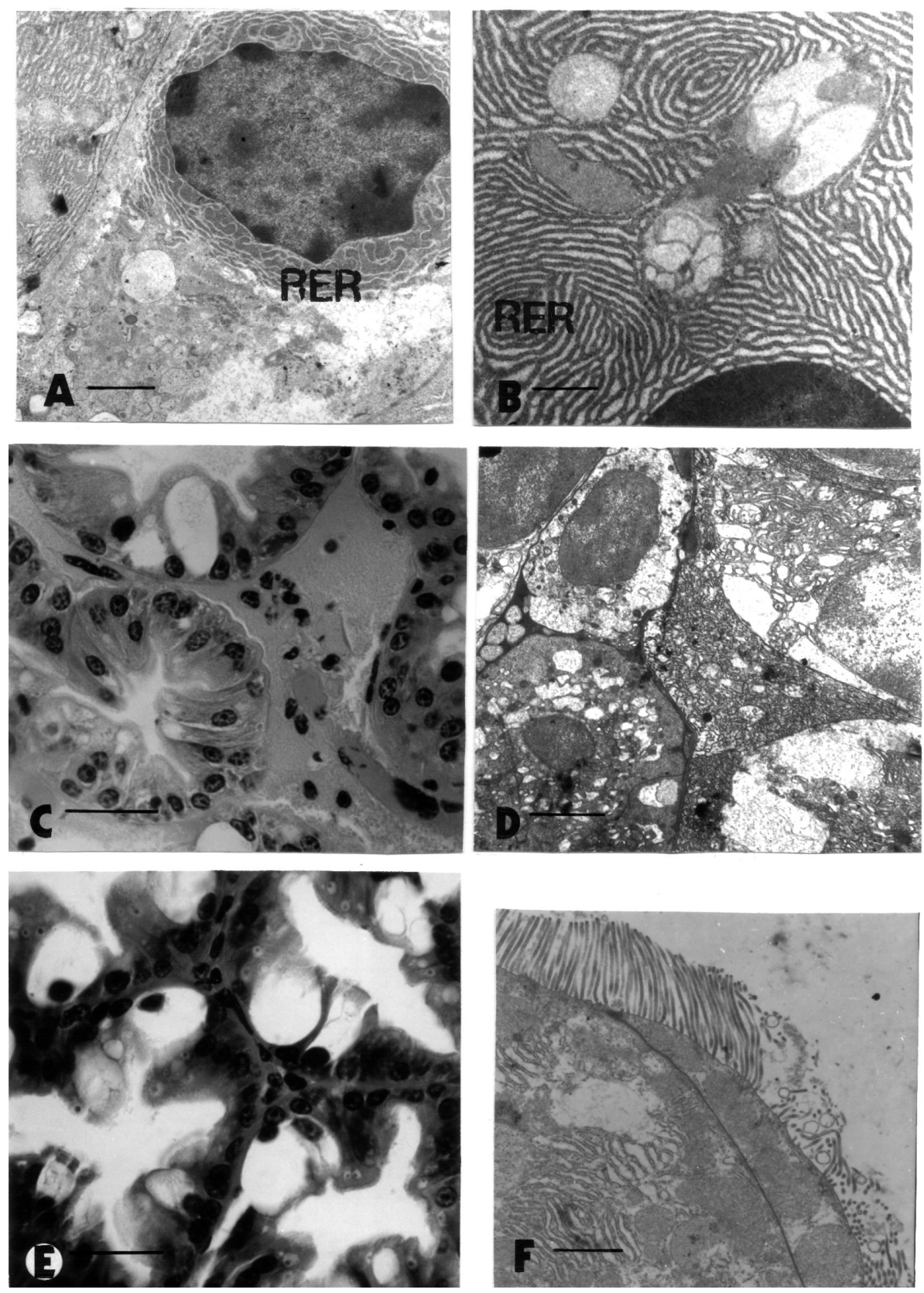

Figure 4 - A, D. Salinity induced alterations in the hepatopancreas after 30 days from the beginning of the experiment. -A. Salinity 8\%o. Pathological cell showing a retracted nucleus, electron-dense rough endoplasmic reticulum (RER) and cytoplasm lysis. Scale bar: $1.8 \mu \mathrm{m}$. - B. Salinity $16 \%$ o. Altered F-cell with nuclear picnosis, electrondense RER cisternae and dilated Golgi cisternae. Scale bar: $0.96 \mu \mathrm{m}$. -C. Salinity $24 \%$. Note the haemocytic infiltration and the infoldings of the tubular basal lamina. Scale bar: $25 \mu \mathrm{m}$. -D. Salinity $24 \%$ o. Detail of infiltrated haemocytes and lytic cells. Scale bar: $1.8 \mu \mathrm{m}$. -E, F. $8 \%$ o salinity induced alterations after 60 days. -E. Hepatopancreatic tubules with irregular lumen and haemocytic infiltration. Cells show a basophilic cytoplasm, picnotic nuclei and disrupted brush border. Scale bar: $25 \mu \mathrm{m}$. -F. Apical zone of two cells ( $\mathrm{F}$ and $\mathrm{R}$ ) with apical lysis, disrupted brush border, and pale mitochondria. Scale bar: $0.96 \mu \mathrm{m}$. 
After 60 days, profound alterations in the organ morphology were observed with the three treatments (Fig. 5A-C). These alterations comprised epithelial atrophy, tubular lumen dilated and irregular, haemocytic infiltration, folded basal lamina, desquamated epithelium, retracted nuclei, and RER membranes infiltrated with an electron-dense material. The different cellular types (E, F, R and B) presented a basophilic cytoplasm losing distinctive features (Fig. 5C). Cellular lysis, infiltration and epithelial desquamation were more conspicuous at 16 and $24 \%$ o than at $8 \%$ o (Fig. 5B, D).
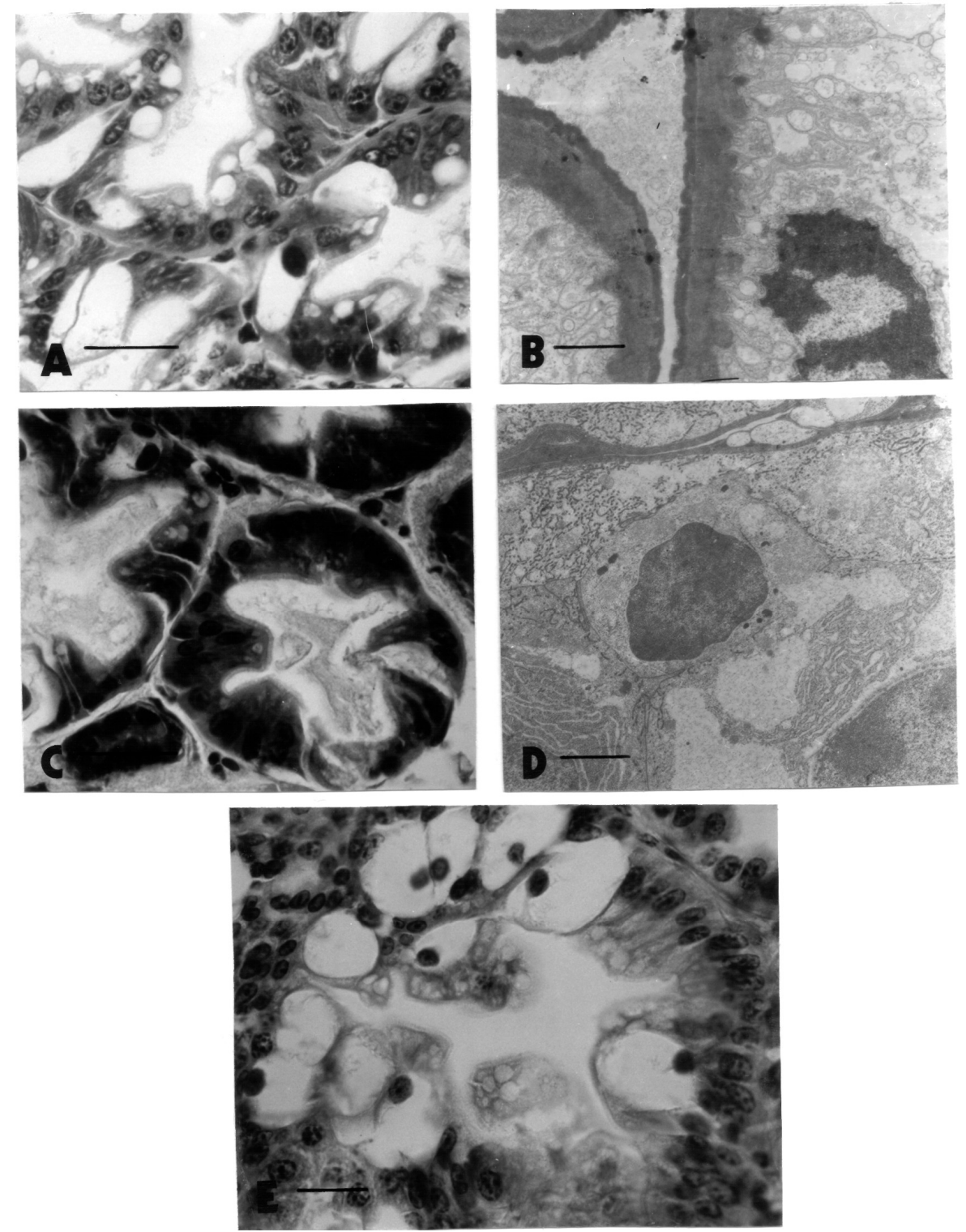

Figure 5 - A, D. Salinity induced alterations in the hepatopancreas after 60 days. -A, B. Salinity 16\%o. -A. Dilated and irregular tubular lumen, cells with picnotic nuclei, basophilic cytoplasm. Scale bar: $25 \mu \mathrm{m}$. -B. Degenerative desquamation of the epithelium, cytoplasm lysis and retracted nuclei with condensed chromatin. Scale bar: $1.8 \mu \mathrm{m} .-\mathrm{C}$, D. Salinity $24 \%$. C- Necrotic epithelium with basophilic cytoplasm, picnotic nuclei and desquamated cells. Scale bar: $25 \mu \mathrm{m}$. -D. Necrotic cells with lysed cytoplasm, electron-dense RER and infiltrated haemocytes. Scale bar: $1.8 \mu \mathrm{m}$. -E. Hepatopancreas of individuals re-acclimated to freshwater from $8 \%$. Note the disorganized epithelium, hypertrophied R-cells and haemocytic infiltration. Scale bar: $25 \mu \mathrm{m}$. 


\section{Hepatopancreas cytology after re-acclimation to freshwater}

In some of the prawns previously maintained at $8 \%$, most of the tubules evidenced cellular recovering at the distal zone, with mitosis of $\mathrm{E}$ cells, and differentiated cells presented a well developed brush border. At the proximal zone, tubules showed a necrotic epithelium and haemocytic infiltration. Other individuals had the hepatopancreas completely deteriorated (Fig. 5E), with haemocytic infiltration, epithelial atrophy, cellular lysis, kariorrexis and disrupted brush border. Ultrastructurally, some cells presented retracted nuclei, cytoplasmolysis, and numerous lysosomes were observed in the cytoplasm of many other cells.
In the hepatopancreas from individuals previously acclimated to 16 and $24 \%$, the tubules showed the epithelium completely atrophied, cellular retraction, degenerative desquamation, disrupted brush border, and the intertubular spaces were very infiltrated with haemocytes (Fig. 6A, C). At ultrastructural level, R-cells were the most affected showing conspicuous alterations (Fig. 6B) such as, cytoplasmolysis, nuclear retraction and cytoplasmic vacuolization. In individuals from $24 \%$ treatment, the tubular epithelium was disorganized and most of the cells were completely altered (Fig. 6C). Ultrastructurally, R (Fig. 6D) and F-cells displayed retracted nuclei with a complete decondensation of chromatin, dilated RER membranes, and pale and swollen mitochondria.
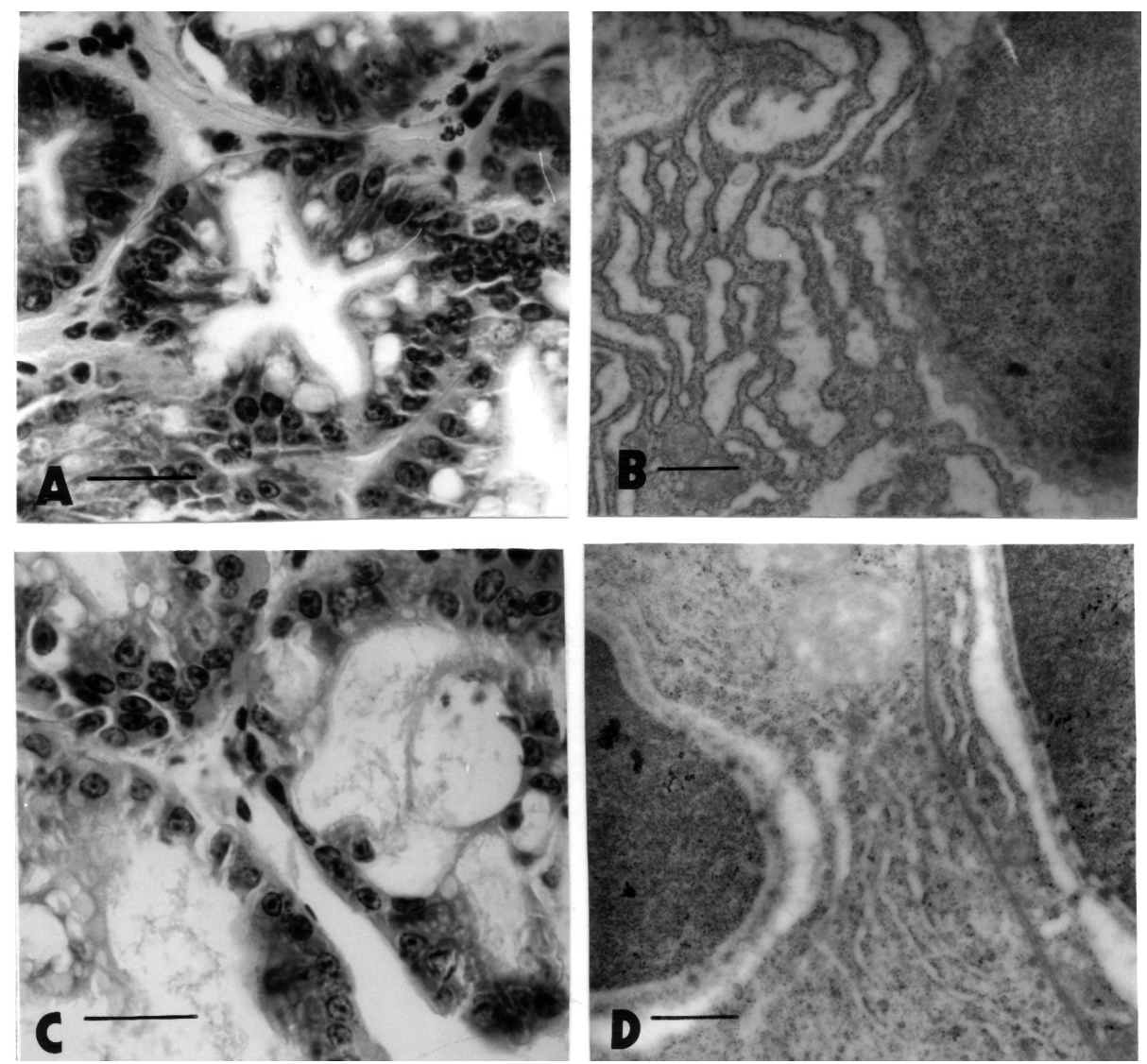

Figure 6 - A, D. Hepatopancreas of individuals re-acclimated to freshwater. -A, B. Re-acclimated from $16 \%$. - A. Cross sectioned tubules showing epithelial lysis, cellular retraction, disrupted basal lamina and haemocytic infiltration. Scale bar: $25 \mu \mathrm{m}$. $-\mathrm{B}$. Detail of R cell without signs of cellular recovery. Scale bar: $0.96 \mu \mathrm{m}-\mathrm{C}, \mathrm{D}$. Re-acclimated from 24\%o. -C. Damaged tubules showing cellular atrophy, disrupted basal lamina, haemocytic infiltration and complete epithelial disorganization. Scale bar: $25 \mu \mathrm{m}$. $-\mathrm{D}$. The cells display the same cytological features as before re-acclimation. Note the retracted nuclei, dilated RER membranes and swollen mitochondria. Scale bar: 0.96 $\mu \mathrm{m}$. 


\section{DISCUSSION}

Many freshwater caridean shrimps are actually euryhaline and can adapt to relatively high salinities in the range of 25 to $33 \%$. Some of these retain the capacity to hypo-regulate in seawater such as Macrobrachium rosembergii (Sandifer et al., 1975) and M. petersi (Read, 1984), while others osmoconform at $24 \%$ and above as Palaemonetes paludosus (Dobkin and Manning, 1964). P. argentinus hyper-regulates at low salinities and hyper-osmoconform or isoregulates at higher salinities up to $32 \%$ (Anger et al., 1994). Under natural conditions, the biological cycle of $P$. argentinus can be accomplished in either freshwater or brackish water (Spivak, 1997).

In the present work, survival of $P$. argentinus was better at low salinities ( 0 and $8 \%$ ) than at high salinities, and decreased with time. Prawns maintained at $0 \%$ o showed a continuous growth along the experiment. However, prawns maintained at the other salinities $(8,16$ and 24\%o) decreased in wet weight. Ponce Palafox et al. (1997) concluded that shrimps showed experimentally survival peaks at salinities near those of the natural habitat. $P$. argentinus is a strict osmoconformer in salinities of about 20 to $32.2 \%$; survival under these conditions is limited to a few days, and in brackish water habitats such as Mar Chiquita lagoon, this shrimp tends to avoid high salinity areas (Anger et al., 1994).

Crustacean hepatopancreas is the most important organ in the general economy because it serves as the main energy reserve for growth and moulting (Johnson, 1980; Cuartas et al., 2003). Physiological stress is often reflected by important cytological changes in this sensitive organ. $P$. argentinus hepatopancreas, as the central site of metabolism, presented severe histological alterations in individuals from all the treatments, except the controls $(0 \%)$. The deterioration of the tubular epithelium is evidenced by the loss of contact between cells and with the basal lamina (Geneser, 2000; Cuartas et al., 2003). This process was progressive in $P$. argentinus as a consequence of the increasing salinity, suggesting a gradual reduction of the metabolic function.

In this work, the tested salinities produced epithelial desquamation, necrosis and folded basal lamina. Folded basal lamina has also observed in individuals under nutritional stress (Storch and Anger, 1983; Díaz et al., 2002). The basal lamina infoldings may be the result of the epithelial retraction and atrophy due to the loss of water at high salinities.

Degenerative desquamation of the tubular epithelium in $P$. argentinus hepatopancreas was a pathological feature observed with all the treatments tested in the present work, being more conspicuous at high salinities. This alteration was also observed in marine crustaceans acclimatized to low salinities, such as Artemesia longinaris (Masson, 2001) and Pleoticus muelleri (Cuartas et al., 2003). According to Vogt (1990), the process of desquamation in the hepatopancreas of $P$. monodon starts with the cells lysis, in particular Rcells, and the neighbouring cells protrude in small basolateral extensions, pushing the damage cells into the tubular lumen generating ulcerations. In $P$. argentinus, the degenerative desquamation is a usual periodic event during the moulting cycle (Sousa and Petriella, 2000; 2001). However, in this prawn, like in P. monodon (Vogt, 1990), A. longinaris (Masson, 2001), and P. muelleri (Cuartas et al., 2003), the increased desquamation produced by different stressors results in a high rate of cell loss that does not make possible the restitution of the damage tissue. This has been mentioned for Litopenaeus vannamei, $L$. stylirostris and Farfantepenaeus californiensis (Lightner and Redman, 1994) infected by the NHP virus, in which necrosis foci with important haemocytic infiltration were also characteristic.

In decapods, phagocytic haemocytes take part in the primary mechanisms of cellular immunity (Factor and Beekman, 1990). Factor and Beekman (1990) showed the phagocytic removal of foreign particles and metabolic debris by circulating haemocytes in the hepatopancreas. Haemocytic infiltration was other feature observed in the hepatopancreas of $P$. argentinus, and with the highest salinities the infiltration of hyaline haemocytes and granulocytes was increased. In this case, infiltration can be interpreted as an inflammatory reaction, caused by the increasing desquamation of necrotic epithelium. This was in coincidence with that observed in the hepatopancreas of A. longinaris (Masson, 2001) and P. muelleri (Cuartas et al., 2003).

Ultrastructural alterations observed in F, R and Bcells of $P$. argentinus indicated the sensibility of these cells to high salinities. The main alterations were detected in $F$ and $R$ cells. $F$ cells are implicated in the synthesis and secretion of digestive enzymes and $\mathrm{R}$ cells store the lipids and glycogen, and are also implicated in the 
detoxification processes (Vogt and Quinitio, 1994; Icely and Nott, 1992; Johnston et al., 1998). The profound damages observed in these cells, particularly in $\mathrm{R}$ cells, such as nuclear retraction, pyknosis, cytoplasmic vacuolization, and cytoplasmolysis largely followed the scheme given by Vogt (1990) and Trump et al. (1981) for this stage of necrosis. It has been suggested that Rcells are the most sensitive to metabolic and environmental changes such as starvation, salinity and pollutants (Storch and Anger, 1983; Masson, 2001; Vogt, 1987; Vogt and Quinitio, 1994). The pathological features mentioned above indicate the eventual cell lysis.

After the re-acclimation to freshwater, the individuals previously maintained at $8 \%$ o showed a reestablishment of the tubular structure at the distal zone of the tubules, while the tubules at the proximal zone were completely damaged. With the other treatments (16 and 24\%o), hepatopancreatic cells evidenced no signs of recovery.

The histological alterations produced by the osmotic stress are detected earlier than differences in the growth or survival, so the histological diagnosis is considered a valuable tool, because of the sensibility of the method to evaluate the physiological state of prawns and the environmental conditions (Vogt, 1987). From the present observations, it could be concluded that there were a long term response to the three salinities, which consisted of an alteration of the functional cytology of the hepatopancreas with a consequent reduction of the metabolic activity. The hepatopancreas possesses great plasticity and reacts to the osmotic stress adapting to the new salinity conditions inside a large gradient, but in long term, this plasticity apparently exceeds. The tolerance to short-term salinity changes explains the capability of this prawn to inhabit in estuarine environments where there are frequent salinity fluctuations.

\section{ACKNOWLEDGEMENTS}

The present work was supported by a grant from Universidad Nacional de Mar del Plata (20032005) and is part of a project financed by Consejo Nacional de Investigaciones Científicas y Técnicas (PIP N $\left.{ }^{\circ} 2882 / 2000\right)$.

\section{REFERENCES}

Al-Mohanna, S.Y. and Nott, J.A. (1989), Functional cytology of the hepatopancreas of Penaeus semisulcatus (Crustacea: Decapoda) during the moult cycle. Mar Biol., 101, 535-544.

Anger, K., Spivak, E., Bas, C., Ismael, D. and Luppi, T. (1994), Hatching rhythms and dispersion of decapod crustacean larvae in a brackish lagoon in Argentina. Helgol. Meeresunters, 48, 445-466.

Bell, T.A. and Lightner, D.V. (1988), A handbook of normal Penaeid shrimp histology. World Aq. Soc. Allen Press, Inc. (USA).

Boschi, E.E. (1981), Decapoda Natantia. Fauna de agua dulce de la República Argentina. Vol. 26. FECIC, Buenos Aires.

Collins, P.A. (1999), Feeding of Palaemonetes argentinus (Decapoda: Palaemonidae) from an oxbow lake of the Paraná River, Argentina. J. Crust. Biol., 19 (3), 485-492.

Cuartas, E.I., Díaz, A.C. and Petriella, A.M. (2003), Modificaciones del hepatopáncreas del langostino Pleoticus muelleri (Crustacea, Penaeoidea) por efecto de la salinidad. Biociencias (Brasil), 11, 53-59.

Charmantier, G., Anger, K. (1999), Ontogeny of osmoregulation in the palaemonid shrimp Palaemonetes argentinus (Crustacea: Decapoda). Mar. Ecol. Prog. Ser., 181, 125-129.

Díaz, A.C., Sousa, L.G. and Petriella, A.M. (2002), Hepatopancreas structure of Palaemonetes argentinus (Decapoda, Caridea) fed different levels of dietary cholesterol. In-Modern Approaches to the Study of Crustacea, eds. E. Escobar-Briones and F. Alvarez. Kluwer Academic/Plenum Publishers, New York, pp 67-73.

Dobkin, S. and Manning, R.S. (1964), Osmoregulatioon in two species of Palaemonetes (Crustacea: Decapoda) from Florida. Bull. Mar. Sci. Gulf Carib., 14, 149-157.

Factor, J.R. and Beeckman, J. (1990), The digestive system of the lobster, Homarus americanus: III. Removal of foreign particles from the blood by fixed phagocytes of the digestive gland. J. Morphol., 206, 293-302.

Geneser, F. (2000), Histología. Sobre bases biomoleculares. Editorial Panamericana, Buenos Aires.

Gibson, O. and Barker, P.L. (1979), The decapod hepatopancreas. Oceanog. Mar. Biol. Ann. Rev., 17, 285-346.

Icely, J.D. and Nott, J.A. (1992), Digestion and absorption: digestive system and associated organs. In-Microscopic Anatomy of Invertebrates: Decapod, Crustacea, Vol. 10, eds. F.W. Harrison and A.G. Humes. Wily-Liss Inc., New York, pp 147-201. 
Johnson, P.T. (1980), Histology of the blue crab, Callinectes sapidus: a model for Decapoda. Chapter 8: The Gills. Praeger, New York, pp 84-100.

Johnston, D.J., Alexander, C.G. and Yellowlees, D. (1998), Epithelial cytology and function in the digestive gland of Thenus orientalis (Decapoda, Scyllaridae). J. Crust. Biol., 18 (12), 271-278.

Lightner, D.V. and Redman, R.M. (1994), An epizootic of necrotizing hepatopancreatitis in cultured penaeid shrimp (Crustacea: Decapoda) in Northwestern Peru. Aquaculture, 122, 9-18.

Loizzi, R.F. (1971), Interpretation of crayfish hepatopancreatic function on fine structural analysis of epithelia cell lines and muscle network. $Z$ Zellforsch, 113, 420-440.

Masson, I. (2001), Efecto del estrés osmótico sobre la morfología funcional del hepatopáncreas de Artemesia longinaris Bate (Crustacea, Decapoda). Tesis de Grado. Fac. Ciencias Exactas y Naturales, Univ. Nac. Mar del Plata, Argentina.

Morrone, J.J. and Lopretto, E.C. (1995), Parsimony analysis of endemicity of freshwater Decapoda (Crustacea: Malacostraca) from Southern South America. Neotropica, 41, 3-8.

Petriella, A.M. and Fonalleras, M.C. (1997), Citoarquitectura del hepatopáncreas del camarón Artemesia longinaris Bate (Crustacea, Decapoda, Penaeidae). Physis Sección A, 55 (128-129), 25-30.

Ponce-Palafox, J., Martinez-Palacios, C.A. and Ross, L.G. (1997), The effects of salinity and temperature on the growth and survival rates of juvenile white shrimp, Penaeus vannamei, Boone, 1931. Aquaculture, 157, 107-115.

Read, G.H.L. (1984), Intraspecific variation in the osmoregulatory capacity of larval, post-larval, juvenile and adult Macrobrachium petersi (Hilgendorf). Comp. Biochem. Physiol., 78A, 501506.

Sandifer, P.A., Hopkins, J.S. and Smith, T. (1975), Observations on salinity tolerance and osmoregulation in laboratory-reared Macrobrachium rosenbergii post-larvae. Aquaculture, 6, 103-114.

Sousa, L.G. and Petriella, A.M. (2000), Histology of the hepatopancreas of the freshwater prawn Palaemonetes argentinus (Crustacea, Caridea). Biocell, 24 (3), 189-195.

Sousa, L.G. and Petriella, A.M. (2001), Changes in the hepatopancreas histology of Palaemonetes argentinus (Crustacea, Caridea) during moult. Biocell, 25 (3), 275-281.
Sousa, L.G., Cuartas, E.I. and Petriella, A.M. (2005), Fine structural analysis of the epithelial cells in the hepatopancreas of Palaemonetes argentinus (Crustacea, Decapoda, Caridea) in intermoult. Biocell, 29 (1), 25-31.

Spivak, E.D. (1997), Life history of a brackish-water population of Palaemonetes argentinus (Decapoda: Caridea) in Argentina. Annales Limnol., 33, 179-190.

Storch, V. and Anger, K. (1983), Influence of starvation and feeding on the hepatopancreas of larval Hyas araneus (Decapoda, Majidae). Helgol. Meeresunters, 36, 67-75.

Storch, V. and Welsch, U. (1977), Elektronenmikroskopische und enzymhistochemische Untersuchungen der Mitteldarmdrüse der landlebenden Decapoden Coenobita rugosus und Ocypode ceratophthalma. Zool Jb (Anatomie Ontogenie Tiere), 79, 25-39.

Trump, B.F., Berezesky, I.K. and Osornio-Vargas, A.R. (1981) Cell death and the disease process. The role of calcium. In-Cell death in biology and pathology, eds. I.D. Bowen and R.A. Lockshin. Chapman and Hall, London, New York, pp. 209-242.

Vogt, G. (1987), Monitoring of environmental pollutants such as pesticides in prawn aquaculture by histological diagnosis. Aquaculture, 67, 157-164

Vogt, G. (1990), Pathology of midgut gland-cells of Penaeus monodon postlarvae after Leucaena leucocephala feeding. Dis. Aquat. Org., 9, 45-61.

Vogt, G. (1994), Life-cycle and functional cytology of the hepatopancreas cells of Astacus astacus (Crustacea, Decapoda). Zoomorphology, 114, 83-101.

Vogt, G. and Quinitio, E.T. (1994), Accumulation and excretion of metal granules in the prawn, Penaeus monodon, exposed to water-borne copper, lead, iron and calcium. Aquat. Toxicol, 28, 223-241.

Vogt, G., Stöcker, W., Storch, V. and Zwilling, R. (1989), Biosynthesis of Astacus protease, a digestive enzyme from crayfish. Histochemistry, 91, 373-381. 